\title{
Development of a zoning management plan for Petra Archaeological Park (PAP), Jordan
}

\author{
Said Damhoureyeh ${ }^{1^{\star}}$, Ahmad Disi ${ }^{1}$, Ibrahim Al-Khader ${ }^{2}$, Mohammed H. Abu-Dieyeh ${ }^{3}$ \\ ${ }^{1}$ Department of Biology, University of Jordan, Amman, Jordan; ${ }^{*}$ Corresponding Author: saidd@ju.edu.jo \\ ${ }^{2}$ Birdlife International, Amman, Jordan; \\ ${ }^{3}$ Department of Biology and Biotechnology, The Hashemite University, Zarqa, Jordan.
}

Received 29 September 2011; revised 2 November 2011; accepted 16 November 2011.

\section{ABSTRACT}

As Petra is increasingly becoming a major tourism destination in Jordan, this underlies not only challenges to conserve the habitats and species in Petra but also offers great opportunities to promote academic research and investigation, demonstrate sustainable development and initiation of environmentally sound development and nature based tourism. This investigation is based on both desktop studies and field missions. The desktop part is relied on reviewing various studies and reports that highlighting natural resources in the area. Two field missions were conducted aiming to document various information from related authorities and institutions operating in Petra and also to undertake ground truthing of habitats and species information. The missions also included interviews with Park staff, representatives from ongoing projects and initiatives in Petra (SeyahaUSAID) and many locals belonging to various tribes in Wadi Musa and The Bdul. The study presents a synthesis to findings from these studies and visits. Broadly, the park can be zoned into three mega zones: 1) Wadi Arabah and the steep gorges to the west including the Artemisia and annual grasses steppe to the west, 2) Mountainous ridges and rocky slopes of the Mediterranean region located almost centrally in the park and at the southern limit and part of the eastern borders and 3) Central basin and steep limestone scarps and weathered sandstone. Based on lists of key and indicator species, some key/sensitive sites of conservation value have been suggested. Aspects of grazing, agricultural activities, tourism and water resources and their implications on management schemes have been discussed.
Keywords: Archaeological Park; Ecotourism; Biodiversity; Environmental Management; Petra; Jordan

\section{INTRODUCTION}

As a result of the increased attention to the concept of nature conservation in Jordan, several national action plans and strategies have been done to discuss the concept of biodiversity conservation on the national level. Among these are: National Environmental Strategy, 1992, National Environmental Action Plan, 1995, and, National Biodiversity Strategy and Action Plan 2003 $[1,2]$. The Environmental Protection law 1/2005 has been recently enacted after the creation of the ministry of Environment. Moreover, there are a number of newly updated regulations and bylaws that promotes biodiversity conservation and mainstream environmental assessments. These include: EIA regulations 37/2005, National Parks/Reserves Bylaw 29/2005 and Soil Protection Bylaw 25/2005.

On the international level, Jordan has signed and became member in several international conventions and agreements on the conservation of nature. Most notably of these are: Ramsar Convention; Convention on International Illegal Trade with Endangered Species (CITES); and Convention for the Conservation of Migratory Species (CMS), Bonn Convention and the Convention on Biological Diversity.

Population increase is considered as the root cause of many environmental implications in Jordan. All studies indicated that habitats of Jordan have been impacted by human activities and their settlements [2-5].

Petra is internationally known for its archaeological heritage, however, there was and still a necessity to better appreciate the natural resources and ecological uniqueness and richness of the Petra region. This inspires not only challenges to conserve biodiversity of habitats and species in Petra but also induces great op- 
portunities to promote academic research and investigation, demonstrate sustainable development and initiate an environmentally sound development and nature based tourism.

The objectives of this investigation are: 1) to identify and gather all existing data and reports which may be useful in preparing of the Zoning Management Plan (ZMP); 2) to identify and delineate mega zones, as well as other sub-zones within, for further investigation and 3) to develop appropriate proposals towards conserving natural resources of Petra Archaeological Park (PAP).

\section{MATERIALS AND METHODS}

Part of the study was relied on reviewing and gathering various studies and reports that highlighting natural resources in the area, based on previous experience of the area and species research. In addition to that two field missions were conducted aiming to document various information from authorities and institutions operating in Petra (i.e. Petra Regional Authority (PRA), Petra Archaeological Park (PAP), Agricultural Department extensions in Petra). The team during field visits managed to have meetings and interviews with a variety of stakeholders within the PAP and the Petra Region. This included PAP staff, Agricultural Department division heads, PRA director; representatives form USAID/ JDTP and other ongoing projects and initiatives in Petra as well as numerous members of local communities from Wadi Musa and the Bdul in Um Seyhun. Field visits to various sites including, City center, Siq area, Turkmani- yya Road, areas and trails leading to Haron tomb were also conducted in order to collect ecological notes about key sites and habitats.

\section{BIOGEOGRAPHY AND ECOLOGY OF THE STUDY SITE}

Jordan is about $100 \mathrm{~km}$ from the south-eastern coast of the Mediterranean Sea, between latitudes $29^{\circ}-33^{\circ} \mathrm{N}$ and longitudes $35^{\circ}-39^{\circ} \mathrm{E}$ and has a land area of about $89,200 \mathrm{~km}^{2}$, of which arable land is less than five percent (Figure 1). The whole of Jordan forms part of the Mediterranean region and is characterized by the Eastern Mediterranean climate, which has a mild and moderately rainy winter and a hot rainless summer. However, spring and autumn do not have specific entity. The country is divided into three topographic regions (Mountainous, Jordan Valley and Wadi Arabah, as part of the Great Rift Valley) and The Eastern Plateau. The rapid changes between these regions in such a small area had enriched Jordan's flora and fauna.

Several authors divided Jordan into four different bioclimatic or bio-geographical regions [6-9]. These are the Mediterranean bioregion or biotope, which encompasses the mountainous region, the Afro-tropical (Known also as Sudanian or Afro-Sindian) that extend along the Jordan valley, the Saharo Arabian that best represented at the eastern plateau, and the Irano-Turanian (or the Steppe region) that forms a narrow belt at the eastern and western sides of the Mediterranean bioregion.

Although, no specific study was conducted on Petra in

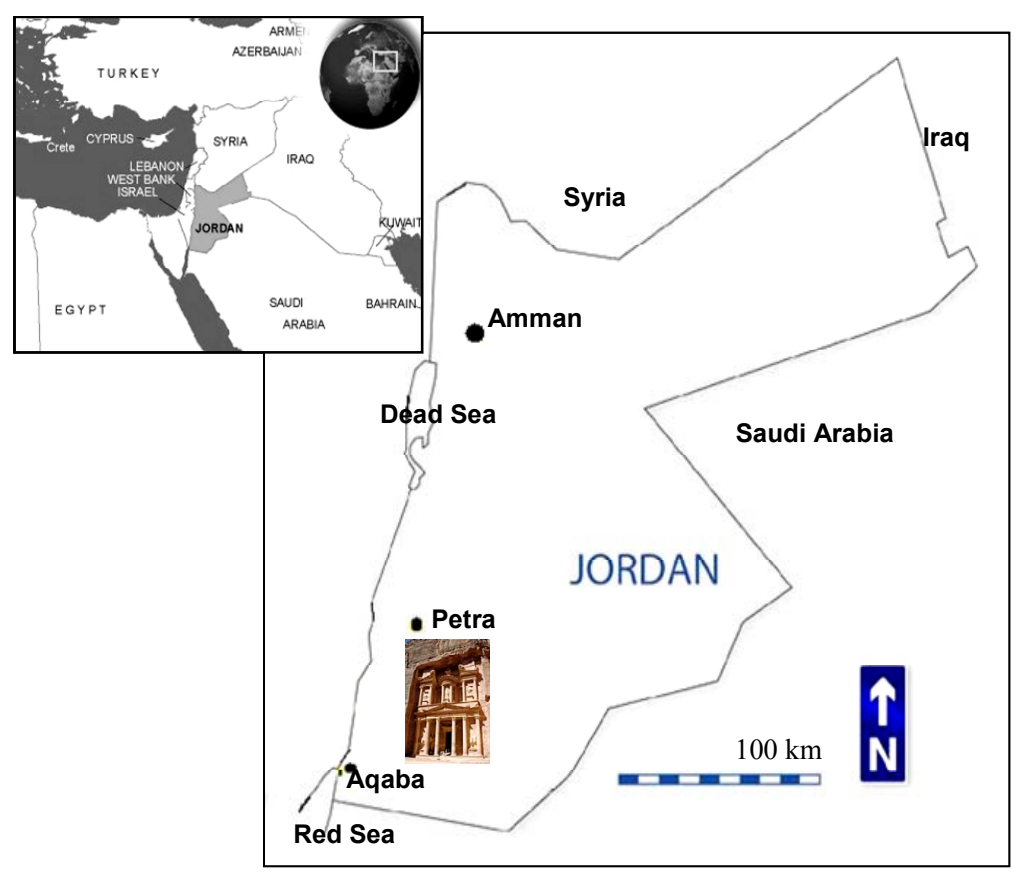

Figure 1. A map of Jordan showing the location of Petra Archeological Park. 
terms of vegetation ecology and vegetation types nevertheless general descriptions can be withdrawn from these various studies; The Petra National Trust (PNT) in collaboration with professors from the universities of Jordan and Yarmouk, with GEF funding conducted a two year project between 94 and 96. This study provided a descriptive survey of the plant and animal population in certain areas within the PAP. The area did not cover the western and southern part of the PAP. It also did not cover the mountainous areas in the North due to access difficulties. While the study has a full description of the floral and faunal species it does not include the ecological measurements required for ecological parameters (coverage, species abundance, frequency, distribution etc.) and GIS mapping.

\subsection{Habitat Diversity}

Petra transects between the three topographic regions, with Wadi Arabah to the far west, steppe vegetation represented by Sandy Hamada as we advance to the east, followed by again a mixed steppe/Saharo-Arabian vegetation, and culminates in the Mediterranean biotope represented by Jniperus phoeanicia (Phoenician Juniper) cliffs and sandstones and other tree vegetation such as Quercus callprinos (Evergreen Oak). The vegetation type starts to change as we continue further east where Artemisia herba-alba steppe and transition steppe/Saharo-Arabian vegetation starts to become more evident.

The topographic diversity in Petra has resulted in diversifying biological habitats as well as associated micro-habitats. Therefore, within the above-identified biotopes, diversity of habitats can be observed such as rocky cliffs and slopes, which dominate the highlands, wadis, runoff and spring systems transecting all through the park, sandy habitats as isolated locations between rocky areas and larger areas as in Wadi Arabah, stony hills escarpments and gravel fans at the eastern and western slopes of highlands with a few remnant forest areas and trees and agricultural fields. More specifically, habitat diversity can be classified into 13 different types, as shown in Table 1.

\subsection{Species Diversity}

Petra is on the border of three biogeographical realms, namely the Palearctic to the north, the Afro-tropical to the south and the Saharo-Arabian both to east and west. These mixed conditions and the unique topography of the Petra area, have allowed for interaction of animals and plants from all three realms, producing an unexpected diversity for such a limited area [10]. In their field guide to the animals and plants of Petra, and based on extensive field surveys to various parts of the park,
Ruben \& Disi 2006 [10], indicated that almost 40\% of all the species that occur in Jordan have been recorded so far in the Petra area, listing and/or describing most of Petra Archaeological Park plants, mammals, Amphibians and reptiles, and Birds. Almost 750 plant species has been reported by previous studies in Petra, however the estimated total of plant species recorded in Jordan is around 2250. Additionally, 42 species of reptiles and amphibians 107 bird species (both resident and migrant) and 31 species of mammals have been recorded in Petra out of 102, 420 and 77 species known to occur in Jordan, respectively. The above figures indicate how rich and diverse the Petra region wildlife is.

Many of these species have significant conservation status at national, regional and international levels. Regarding plants of Petra region at least 25 species are considered endemic to Jordan and to the Eastern Mediterranean region and more than 30 species are considered threatened at both national and regional levels including tree species. Many are locally and nationally rare (Table 2). All these do occur in various habitats within the PAP. Moreover, Petra is the southern limit of distribution of Phoenician Juniper in Jordan, and virtually the northern limit (in addition to Wadi Arabah) for Acacia trees in the Arabian Peninsula [11-13].

For mammals, which do enjoy a wider home range and expected to be found in most habitats (with special habitat preferences depending on the species), many have significant conservation status such as three species of foxes,

Table 1. Classification of habitats encountered in Petra National Park.

\footnotetext{
1) Artemisia, steppe and grassland brush to west and east of mountainous ridges.

2) Steep limestone scarps in the Mediterranean region and within the mountainous ridges.

3) Several steep gorges and block fans on granite mainly on the western part of the Park

4) Weathered sandstone with scrub

5) Sandy Wadis with Retama raetam and others

6) Bare bed rock

7) Gravel hills and plains to the east.

8) Scattered Acaccia trees in wadis towards the west

9) Open Acacia woodland in Wadi Arabah

10) Juniper wood scattered along the highlands

11) Wadis with Oleander intersecting various parts of the park.

12) Scrub woodland of Quercus calliprinos (outside the Park area) with individual trees within the Park

13) Cultivation and agricultural fields (fodders and crops)
} 
Table 2. List and conservation status of plant species inhabiting Petra region (Source: GCEP, 2000a [11]).

\begin{tabular}{|c|c|c|c|c|}
\hline Family name & Species name & English name & Status & Habitat \\
\hline \multirow[t]{2}{*}{ ANACARDIACEAE } & Pistacia atlantica & Atlantic pistachio & Threatened & Mountains, steppe, and open woodlands \\
\hline & Pistacia khinjuk & & Endemic, Threatened & Steppe, among shrubs. Very rare \\
\hline APIACEAE & Ferula sinaica & & Endemic & Desert and sandy grounds of Edom \\
\hline \multirow[t]{2}{*}{ ASCLEPIADACEAE } & Calotropis procera & Sadom's Apple & Threatened & Tropical areas \\
\hline & Caralluma sinaica & & Threatened & Rocky grounds in Jordan valley \\
\hline \multirow[t]{9}{*}{ ASTERACEAE } & Anthemis edumea & & Endemic & Western Steppe facing Wadi Arabah \\
\hline & Anthemis maris-mortui & & Endemic & Wadi in Hammada, desert region \\
\hline & Anthemis nabataea & Nabataean Daisy & Endemic & Steppe areas \\
\hline & Chrysanthemum coronarium & Crown daisy & Threatened & Fallow fields on various soils \\
\hline & Cousinia dayi & & Endemic & $\begin{array}{l}\text { Roadsides and disturbed grounds in high } \\
\text { mountains Stony fields above } 1000 \mathrm{~m}\end{array}$ \\
\hline & Cousinia moabitica & & Endemic & Stony fields above less than $1000 \mathrm{~m}$ \\
\hline & Filago inexpectata & & Endemic & Alluvial soils \\
\hline & Picris amalectana & & Endemic & Sandy soils in deserts and steppe regions \\
\hline & Tragopogon collinus & & Threatened & Rocky desert and steppe on sandstone \\
\hline BALANITACEAE & Balanites aegyptiaca & Egyptian Balsam & Threatened & Hot deserts, oases and wadis of Jordan Valley \\
\hline BORAGINACEAE & Heliotropium maris-mortui & & Endemic & Arid slopes of hills facing Wadi Arabah \\
\hline \multirow[t]{3}{*}{ BRASSICACEAE } & Arabis nova & Rock-cress & Threatened & Batha \\
\hline & Hesperis pendula & & Threatened & Batha among rocks \\
\hline & Matthiola arabica & & Endemic & $\begin{array}{l}\text { Open ground, stony or sandy in various } \\
\text { habitats }\end{array}$ \\
\hline \multirow[t]{2}{*}{ CUPRESSACEAE } & Cupressus sempervirens & Funeral Cypress & Threatened & Limestone soils (rendzina) \\
\hline & Juniperus phoenica & Phoenician Juniper & Threatened & Rocky sandstone slopes \\
\hline FABACEAE & Astragalus aaronsohnianus & Milk Vetch & Endemic & Sandstone hills of Petra \\
\hline FAGACEAE & $\begin{array}{l}\text { Quercus calliprinos } \\
\quad(=Q . \text { coccifera })\end{array}$ & Kermes Oak & Threatened & Upland areas often on limestone soils \\
\hline GLOBULARIACEAE & Globularia arabica & Arabian Globularia & Threatened & High, Sandy and rocky, dry mountains \\
\hline \multirow[t]{4}{*}{ IRIDACEAE } & Crocus moabiticus & Moab Crocus & Endemic & Fallow fields \\
\hline & Iris edomensis & Edom Iris & Endemic & Open hillsides \\
\hline & Iris petrana & Petra Iris & Endemic & Steppe and marginal areas \\
\hline & Romulea petraea & Romulea of Petra & Endemic & Sandy soils in Petra area \\
\hline \multirow[t]{2}{*}{ LAMIACEAE } & Ballota philistaea & & Endemic & Mainly on sandy loams among shrubs \\
\hline & Phlomis platystegia & & Endemic & Rocky slopes in deserts \\
\hline \multirow[t]{3}{*}{ LILIACEAE } & Aloe vera & Aloe & Threatened & Rocky and sandy slopes in Petra \\
\hline & Colchicum tunicatum & & Endemic & Gravely and clayey open steppe \\
\hline & Tulipa systola & Wild Tulip & Threatened & Rocky slopes in limestone mountains \\
\hline MIMOSACEAE & Acacia raddiana & Acacia & Threatened & Hot wadis at low altitudes \\
\hline
\end{tabular}




\begin{tabular}{|c|c|c|c|c|}
\hline & Acacia tortilis & Acacia & Threatened & Hot wadis at low altitudes \\
\hline MORINGACEAE & Moringa peregrina & & Threatened & Along rocky and stony wadis \\
\hline ORCHIDACEAE & Epipactis veratrifolia & $\begin{array}{l}\text { Scarce March } \\
\text { Helleborine }\end{array}$ & Threatened & $\begin{array}{l}\text { Near springs and water courses along with } \\
\text { Phragmites and Typha }\end{array}$ \\
\hline PALMAE & Phoenix dactylifera & Date Palm & Threatened & Hot wadis with water \\
\hline PAPAVERACEAE & Glaucium grandiflorum & Red Horned poppy & Threatened & Steppe, roadsides and disturbed ground \\
\hline POLYGONACEAE & Calligonum comosum & & Threatened & Sands and sand dunes in Wadi Arabah \\
\hline RESEDACEAE & Ochradenus baccatus & & Threatened & Hot, dry and tropical areas and wadis \\
\hline RHAMNACEAE & Ziziphus spina-christi & Christ's Thorn & Threatened & Low altitude hot areas, wadis and fields \\
\hline ROSACEAE & Amygdalus korschinskyii & Wild Almond & Threatened & Disturbed Oak forested areas, maquis-steppe \\
\hline SALVADORACEAE & Salvadora persica & Toothbrush Tree/Siwak & Threatened & Hot deserts, oases and sometimes saline solis \\
\hline \multirow[t]{3}{*}{ SCROPHULARIACEAE } & Kickxia aegyptiaca & Egyptian Toadflax & Endemic & Desert areas \\
\hline & Kickxia petrana & Petra Toadflax & Endemic & Rocky deserts \\
\hline & Scrophularia nabataeorum & & Endemic & Rocky places \\
\hline SOLANACEAE & Lycium petraeum & Boxthorn & Endemic & $\begin{array}{l}\text { Stone walls surrounding fields in Petra } \\
\text { area steppe regions }\end{array}$ \\
\hline \multirow[t]{2}{*}{ TAMARICACEAE } & Tamarix jordanis & Jordan Tamarisk & Threatened & $\begin{array}{l}\text { Dry sandy areas and wadi beds at streams } \\
\text { and fresh water bodies }\end{array}$ \\
\hline & Tamarix palaestina & Tamarisk & Endemic, Threatened & Saline Water streams \\
\hline ZYGOPHYLLACEAE & Seetzenia lanata & & Endemic & $\begin{array}{l}\text { Hot deserts and pebbly wadi beds in Wadi } \\
\text { Arabah }\end{array}$ \\
\hline
\end{tabular}

wolf, striped hyena, Ethiopian hedgehog, two species of bats, wild cat, rock hyrax, Nubian ibex, porcupine, and dorcas gazelle (Table 3) [14,15].

Almost all herpetofauna (amphibians and reptiles) of Petra are significant for conservation action and their numbers are declining to various reasons but mainly destruction of habitats (Table 4). The Petra Rock Lizard, of a Palearctic origin is considered a relict species, and although species have their own habitat preferences but some are expanding such as the Black Desert Cobra, others like Saw-scaled Viper, which has a steppe habitat preference but is penetrating into the Mediterranean biotope $[16,17]$. The Jordan Rift Valley is a major corridor for bird migration between Eastern Europe and Africa. Additionally, Petra has been also identified as an Important Bird Area (IBA) according to BirdLife International criteria of designation of IBAs [18]. Of the significant species recorded from Petra are: The Globally threatened Lesser Kestrel (migrant and summer visitor in low numbers), and the Imperial Eagle (Rare migrant). Other threatened species and declining in numbers include: the Lammergeier (Possible very rare resident), Griffon Vulture (very rare resident in neighboring mountains), Honey Buzzard (migrant), Egyptian Vulture (migrant and used to nest in Petra), Sooty Falcon (summer visitor and rare breeder) and the Sinai Rose finch (resident) in addition to many restricted range migrating and resident species (Table 5) [16,19,20].

The above, truly indicates that Petra is a living museum of highly diversified landscape, habitats and species hence, several studies presented various recommendations to conserve the wealthy natural heritage in the park. These recommendation basically calls upon: Promoting Eco-tourism, minimizing overgrazing and wood collection and logging and developing and implementing of wildlife rehabilitation programs and mainstream birds conservation especially the threatened species, and is missing from, to the overall management plan for the Park.

\section{RESULTS AND DISCUSSION}

\subsection{Broad Zoning of the Petra Archeological Park}

Based on field work and the available literature, some mega biological zones can be identified within PAP. Such subdivision is triggered mainly by the topography. Nevertheless, each mega zone does include a mixture of 
Table 3. List of recorded mammal species and their conservation status in Petra region. (Source: GCEP, 2000c [13]).

\begin{tabular}{|c|c|c|c|c|c|}
\hline Scientific name & Common name & National status & IUCN status & Others & Habitats \\
\hline Rhinopoma microphyllum & Larger Rat-tailed Bat & Vulnerable & & & $\begin{array}{c}\text { Desert habitats, Shallow open caves, } \\
\text { houses and ruins }\end{array}$ \\
\hline Rhinopoma hardwickei & Lesser Rat-tailed Bat & Vulnerable & & & $\begin{array}{c}\text { Arid habitats, Shallow open caves, } \\
\text { houses and ruins }\end{array}$ \\
\hline Tadarida teniotis & European Free-tailed Bat & Vulnerable & & & Rocky areas with cliffs \\
\hline Eptesicus bottae & Botta's Serotine Bat & Vulnerable & & & Arid regions \\
\hline Pipistrellus bodenheimeri & Bodenheimer's pipistrelle & Rare & & & Arid regions/Wadi Arabah \\
\hline Plecotus austriacus & Grey Long-eared Bat & Vulnerable & & & Caves, ruins and underground tunnels \\
\hline Hystrix indica & Indian Crested Porcupine & Vulnerable & & & Rocky wadis with vegetation \\
\hline Canis lupus & Wolf & Endangered & & & Diverse habitats but avoid true deserts \\
\hline Vulpes vulpes & Red Fox & Common/Vulnerable & & & Diverse habitats but avoid true deserts \\
\hline Vulpes ruppelli & Sand Fox & Endangered & Insufficiently Known & & Deserts and steppe areas \\
\hline Vulpes cana & Blandford's Fox & Vulnerable & Insufficiently Known & CITES II & Cliffs and rocky mountains \\
\hline Hyaena hyaena & Striped Hyena & Vulnerable & & & $\begin{array}{l}\text { Earth dens in all habitats favoring dry } \\
\text { deserts, rocky hills, wadis }\end{array}$ \\
\hline Felis silvestris & Wild Cat & Vulnerable & & & $\begin{array}{l}\text { Semi arid wadis with vegetation and } \\
\text { permanent water }\end{array}$ \\
\hline Felis (caracal) caracal & Caracal & Endangered & Rare & CITES I & Arid regions \\
\hline Capra ibex nubiana & Nubian Ibex & Endangered & Rare & & $\begin{array}{c}\text { Rocky cliffs and steep mountains near } \\
\text { water }\end{array}$ \\
\hline
\end{tabular}

Table 4. List of herpatofauna species and their conservation status in Petra region. (Source: Disi, 2002 [7]).

\begin{tabular}{|c|c|c|c|c|}
\hline Scientific name & Common name & National status & Others & Habitats \\
\hline Testudo graeca terrestris & Spur-thighed Mediterranean Tortoise & Vulnerable & CITE II & $\begin{array}{c}\text { Variable, open forest, sparsely vegetated } \\
\text { and semi arid areas }\end{array}$ \\
\hline Chamaeleo chamaeleon recticrista & Common Chameleon & Conservation Dependent & & Trees and shrubs in various habitats \\
\hline Lacerta kulzeri petrae & Petra Rock Lizard & Relict species & Endemic & $\begin{array}{c}\text { Arid Habitats/Wadi Arabah on rocks } \\
\text { and wadi beds }\end{array}$ \\
\hline Natrix tessellata & Diced Water Snake & Vulnerable & & Permanent water bodies \\
\hline
\end{tabular}

habitats that can be potentially delineated but remains out of scope of the current phase of the study. Broadly, the park can be zoned as the following (Figure 2).

\subsubsection{Zone 1: Wadi Arabah and Steep Gorges to the West Including the Artemisia and Annual Grasses Steppe to the West}

These comprise a large part of the park, with difficulty of access at some sites specially the steep slopes. Various types of habitats can be observed in this zone in- cluding the types: $1,3,5,7,8,9,11$ and 13 (Table 1). Although this zone comprises a major portion of the park, however, this is the least studied zone. Various studies were made on plants, animals and birds of Wadi Arabah in general, and even at close areas such as similar areas within the Dana Wildlife Reserve to the north of the Park and Jabal Masauda (a proposed protected area, by the Royal Society for the Conservation of Nature (RSCN) to the South of the Park).

Main land usage of these areas is grazing, and recently 
Table 5. List of bird species and their conservation status in Petra region (Source: RSCN, 2000 [19]).

\begin{tabular}{|c|c|c|c|}
\hline Scientific name & Common name & Status & Habitat \\
\hline Ciconia ciconia & White stork & Migrant, declining & Open cultivated areas near water, seen only in migration \\
\hline Pernis apivorus & Honey Buzzard & Migrant, declining & Forested areas \\
\hline Neophron percnopterus & Egyptian Vulture & Migrant/Threatened & $\begin{array}{c}\text { Open plains, mountains, deserts and cultivated country } \\
\text { but not forested areas }\end{array}$ \\
\hline Gyps fulvus & Griffon Vulture & Migrant, declining & Open dry valleys, or plateaus \\
\hline Aquila heliaca & Imperial Eagle & Migrant, Threatened & Plains, marches and open fields. Nest on big trees \\
\hline Falco naumanni & Lesser Kestrel & Breeding, migrant, Threatened & $\begin{array}{c}\text { Desert, steppes and open country. Cliffs important } \\
\text { for breeding }\end{array}$ \\
\hline Falco concolor & Sooty Falcon & Migrant, breeding, declining & Rocky sandstone mountains \\
\hline Ammoperdrix heyi & Sand partridge & Residnet resrtricted ranege & Semi arid habitats \\
\hline Turdoides squamiceps & Arabian Babbler & Resident, rare & Arid, bushy habitats near cultivation \\
\hline Onychognathus tristramii & Tristram's Grackle & Resident, restricted range & $\begin{array}{l}\text { Rocky hills, and wadis with scattered vegetation, } \\
\text { semi-desert with Acacia trees }\end{array}$ \\
\hline Serinus syriacus & Syrian Serin & Resdident, Threatened & Open vegetated areas \\
\hline Carpodacus synoicus & Sinai-rosefinch & Resident & Rocky cliffs \\
\hline
\end{tabular}

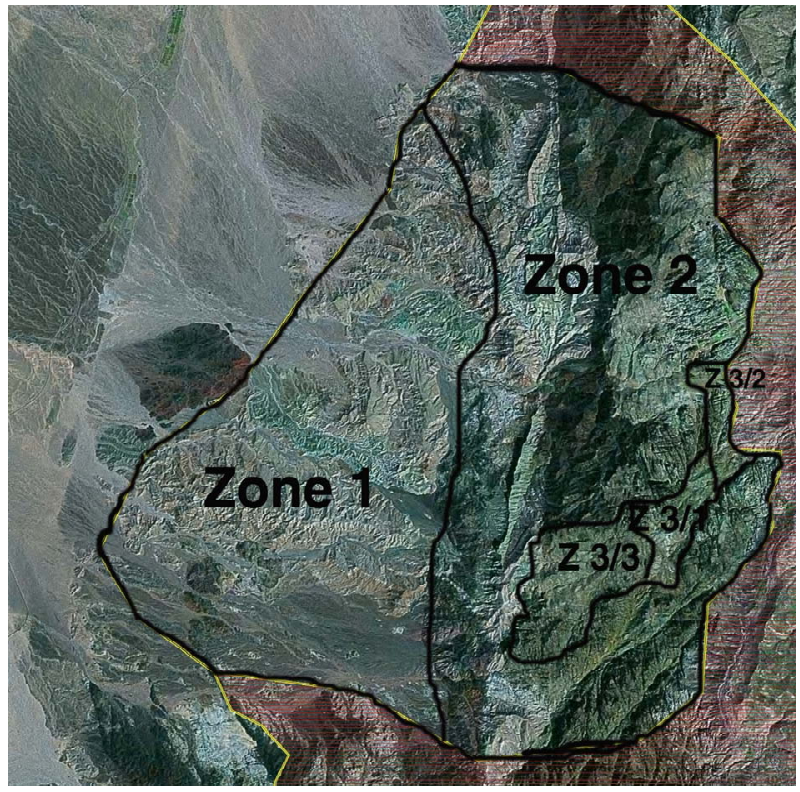

Figure 2. A map of Petra, Jordan showing the three suggested mega zones of Petra Archeological Park.

is witnessing expansion of agricultural projects. Wood collection and logging is also practiced. This part is evidently part of the Jordan Valley migration corridor, and could be a target for environmentally friendly development and ecotourism (especially bird watching) development. The site requires more extensive research to document its biological characteristics and to enable delineation of various habitats occurring within.

\subsubsection{Zone 2: Mountainous Ridges and Rocky Slopes of the Mediterranean Region Located Almost Centrally in the Park and at the Southern Limit and Part of the Eastern Borders}

These are mostly inaccessible. Habitats at these parts are 2, 4, 6, 10, and 11 (Table 1). Some detailed surveys on plants and animals (through Petra National Trust (PNT) projects) have been conducted especially where some archaeological sites exist (Altar, Monastery, etc) and at the eastern ridges overlooking the Siq area. However, extensive survey of these could be in-practical and hence these zones are better designated as no go zones. At sites where routes exist towards some archaeological areas, environmentally sound practices should be promoted, carrying capacity should be estimated and monitoring programs should be developed.

The ridges at the southern borders of the Park are as well inaccessible as zone 1; it is recommended that these are designated as no go zones. An ambiguous concern at these ridges is grazing. A more discussion on grazing is presented later below.

\subsubsection{Zone 3: Central Basin and Steep Limestone Scarps and Weathered Sandstones}

This is where major tourism activity is taking place and includes the city centre. The main types of habitats are 4, 5, 7, 11 and 13 (Table 1). These habitats have been extensively studied by PNT previous projects. This 
zone can be subdivided into three subdivisions: 1) City Center (Roman Road up to Turkomania), a largely eroded area and much disturbed. There is some presence of Sea Squill (Urginia maritia) that has become dominant in the area in the absence of other species that have been lost due to disturbance 2) Zone north to City Center. This area consists of weathered sandstone scrub, sandy wadis with Retama raetam and others, bare bed rock and gravel hills and plains type of habitats. Although, these areas are not yet heavily impacted, with the increasing number of tourists, however, it's important to develop appropriate conservation and monitoring programs. The zone is subject to grazing, agriculture, and has an abundance of tourism related facilities 3) Gravel hills and plains running south-west of the city center and overlooking Wadi Arabah, including Mount Harun site, virtually separating Northern and central mountainous ridges from southern ridges.

\subsection{Key Conservation Sites within the PAP}

Tables 2-5 which lists key and indicator species of plants, mammals, herpetofauna and birds, suggest some key/sensitive sites of conservation value. Although these habitats and the microhabitats created within do respond to one or more of the above mentioned types, and hence more focus is given to identify these.

\subsubsection{Rocky Cliffs and Slopes}

Rocky cliffs largely present within the PAP. Such sites are considered vital to biodiversity as they are important for several breeding birds (Sinai Rose finch, Lesser Kestrel) and mammals such as the Nubian Ibex. These are basically present in Zone 1 of the suggested zoning above.

\subsubsection{Sandstone Mountains}

These are important sites to support Phoenician juniper, and mammals such as the Hyrax spp. and some breeding birds such as sooty falcon. Again these constitute a major part of Zone 1 which largely encompasses mountainous limestone and sandstone ridges.

\subsubsection{Open Hillsides and Weathered Sandstones}

These mainly occur within the central basin and include the gavel hills and plains within zone 3. They provide suitable habitats for several endemic and threatened plant species such as Iris edomensis.

\subsubsection{Wadis and Runoffs}

These are of particular significance and intersecting through various topographic regions within the PAP with varying depths and lengths. Hence they do occur within the three zones. They cross through mountainous ridges, Sandstones hills and even desert. These are important since they provide moisture to sustain green growth, and source of many life forms (plants, mammals, herpetofauna, birds). Some do have water flowing all year long and some are only flooded during rainy season (and snow melting). Some are rocky in nature but many others are sandy. This diverse nature of Wadis reflects their biological role to sustain existing life forms. Wadis within the Mediterranean biotope are usually characterized by the domination of the Oleander. As wadis run into desert and as wadis descend towards the steppe regions, the dominant species becomes the Ratem.

\subsubsection{Sandy Areas, Sand Dunes and Other Desert Habitats}

Very unique sites that do occur at few sites within the PAP but mainly concentrated in Zone 2 . These constitute important habitats to sustain variety of wild plants and animals.

\subsection{Extra Findings from the Field Visits}

The team during field visits managed to have meetings and interviews with a variety of stakeholders within the PAP and the Petra Region. The discussions revealed some key facts regarding the PAP which would require more elaboration and investigation to enable putting forward suitable adaptive management schemes and zoning. These issues include:

\subsubsection{Grazing within the PAP and Role in Habitat Destruction}

There were no specific studies elaborating the grazing pattern and its impacts on natural resources in the area. Around 3000 sheep, 7000 goats, 70 camels, 400 donkeys and mules, 400 horses owned by locals do graze within the park and adjacent boundaries, affecting the archaeological resources/monuments through their movement and at the same time damaging the natural habitats. Overgrazing by goats has been prevalent for centuries in Jordan. Very likely flocks grazed on the steppe area to the east and during drought they began to encroach on forest margins. Contrary to sheep grazing, goats not only eat leaves and shoots of the tree, they also destroy seedlings and ground vegetation, thus preventing plant regeneration.

Steppe habitats in Jordan are best used for herbivory activities. Such sites within PAP emerge as candidate alternative sites to the highlands. However, a rangeland management assessment and a plan based on detailed studies and surveys should be done before reaching a decision regarding the areas in which grazing should be permitted or banned totally in the PAP. 


\subsubsection{Agricultural Activities}

Several agricultural activities are taking place within the PAP. Some are at a very limited scale on the lands inhabited by approx. 20 Bdul families living in Stouh Nabi Haroun in caves, and in tents. There is some construction for storage and limited dwelling (this construction is not licensed). There is evidence of unauthorized agriculture for (fodder and crops mainly Olives) within the Park boundaries on the publicly owned lands.

Agricultural practices need to be monitored and usage of fertilizers and pesticides should be assessed. Such encroachment onto natural landscapes could result in medium-long term impacts on habitat and species diversity. A couple of treated waster projects have been initiated in Petra, Such interventions can provide alternatives and source of income to locals for fodder cropping and agriculture in designated sites outside the PAP.

\subsubsection{Tourism Related Activities}

In $2005 \& 2006$ the number of tourists visiting Petra was estimated about 393 and 360 thousand respectively. In 2007, the number increased to reach about 577 thousand. With the declaration of Petra as one of the World's Wonders, the number of visitors is expected to increase to reach $1,000,000$ per year (personal communication with Mr. G. Nasser, Petra national trust, Amman, Jordan). This tremendous increase in number of visitors has its potential challenges of sustainably managing the site and conservation of its natural resources. Of the concerns to be addressed are: 1) Regulating establishment of Tourist camps inside the PAP ensures environmental compatibility of their operations to reduce impacts on natural resources (vandalism, noise, solid and liquid waste, etc). This requires that developing and rigorous implementation of an Environmental Impact Assessment (EIA) protocols for future permission of sites and facilities. 2) Designation of fixed tourists trails need to be determined. Some of these trails could require animals transport, and hence movement of animals and transport need to be likewise organized at specific, environmentally accepted trails and not allowed for all areas. This in turn requires more assessment to develop appropriate planning. 3) In order to accommodate the increased influx of tourist, there is a suggestion to have separate entrance and exit points to and from the PAP respectively. A similar, approach should be subject to a rigorous EIA especially if vehicular transport (to include type of fuel used, emissions, road requirements etc.) within the PAP is envisaged as one of the options facilitating this process.

\subsubsection{Water Resources}

The Park is highly dissected with wadis and runoffs of varying sizes and lengths, with some permanent water present all the years, temporal ponds and runoffs especially from mountains towards lower areas and Wadi Arabah. There is no specific study regarding water, especially rain water cycle within the PAP. At several sites, road/trails construction mainly at mountainous ridges has caused redirection water runoffs and this in turn has its impact on downstream habitats. Dying back of Juniper trees at some sites could be the result of blockage and redirection activities. Hydrological study of the PAP stems as an important for urgent assessment and study.

\subsection{Other Concerns Affecting Wildlife}

The following are other problems that have been observed during field visits or known from the interviews with locals: wood cutting and collection; illegal excavation and illicit sales of findings; introducing of exotic species to the site (plants, trees, stray dogs and feral animals,); and Vehicular movement within the PAP.

\section{CONCLUSIONS}

The current study is a status report based on the present situation and on previous studies. Previous ecological studies didn't cover the whole parts of the PAP. For accurate and more detailed zoning of PAP than the above broad zoning, more extensive research and data gathering from all sites especially the unstudied ones is needed. New research methodologies, using, GIS knowledge, introducing remote sensing techniques can also be envisaged. All sites that are not studied well yet should be designated as no go zones for development, until such studies and assessments could be conducted. However, and for developmental purposes, an EIA protocol should be enforced to asses the impacts of any suggested development within each of these broad zones.

Grazing remains a major concern, not only in Petra but also in the Jordan valley and Wadi Arabah, and this requires preparing appropriate research appraisals to understand this activity and accordingly to make appropriate recommendations for the purpose of the development of the zoning management plan. Some of the studied and visited areas show the devastating impact of grazing to these sites. No regulations controlling this activity are in place within the PAP, and this activity is taking place virtually everywhere within the PAP and outside it. Better understanding of grazing patterns and socio-economics related to this activity needs to proceed in parallel with a rangeland rehabilitation program to impacted areas whenever possible (e.g. Mount Harun area).

Institutional and human capacity development are needed to provide adequate training and capacity building on conserving and monitoring wildlife, ecotourism 
and to identify threatened species and implement monitoring programs. There are widely accepted programs that can be used such as Nature reserve monitoring programs implemented in Wildlife Reserves in Jordan by RSCN, and the Global IBAs Monitoring Framework (BirdLife International, 2004). The monitoring program is a research program to develop the tools necessary to monitor and assess the environmental and social settings status and trends in response to the different development activities. Also, it is necessary to assess the institutional performance against and compliance with the regulations and standards in order to protect people's health and safety, and the environment health and performance. Establishing an environmental unit within the PAP and/or provide adequate training of senior staff and orientation of project staff is also considered as a cost effective means to reduce impacts. In order to fulfill the awareness and training requirements: 1) Training requirements for each operational unit within the PAP and PRA should be identified and then established; 2) Personnel should be trained in their specific environmental responsibilities that are directly related to significant aspects, targets, and objectives of the site management; 3 ) Personnel that do not have a significant functional role should receive a kind of awareness training programs.

\section{ACKNOWLEDGEMENTS}

We wish to thank PNT and USAID program for providing the financial support.

\section{REFERENCES}

[1] MMRAE (Ministry of Municipal and Rural Affairs and the Environment) (1991) National environment strategy for Jordan: A resource book of information and guidelines for action. IUCN, Gland, Switzerland, 205 Pages.

[2] MMRAE (Ministry of Municipalities, Rural Affairs and Environment) (2002) Jordan agenda 21: Towards sustainable development. MMRAE/UNDP/Capacity 21, 212 Pages.

[3] Hatough-Bouran, A. and Disi, A.M. (1991) History, distribution, and conservation of large mammals and their habitats in Jordan. Environment Conservation, 18, 19-32. doi: $10.1017 / \mathrm{S} 0376892900021251$

[4] Disi, A. and Oran, R. (1995) Biodiversity of Jordan, faunal biodiversity. Third Jordanian Scientific Week. Earth Resources towards Better Use, 5, Ecology: 27-60 (in Arabic).

[5] GCEP (General Corporation for Environmental Protection) (1998) Jordan country study on biological diversity. With technical support from UNEP and funding from GEF, Amman, Jordan, 72 Pages.

[6] Poore, M. and Robertson, V. (1964) An approach to the rapid description and mapping of biological habitats based on a survey of the Hashemite Kingdom by Hunting Technical Services Ltd. and on the work of the British, Jordan expedition, 1963, Sub-Commission on Conservation of terrestrial Biological communities. International Biological Programme (C/O the Nature Conservancy, 19 Belgrave Square, London S.W.I), 68 Pages.

[7] Al-Eisawi, D.M. (1985) Vegetation of Jordan. In: Hadidi, A. Ed., Studies in the History and Archaeology of Jordan, I, Department of Antiquities, Amman, Jordan, 45-56.

[8] Disi, A. and Amr, Z. (1998) Distribution and ecology of Lizards in Jordan (Retilia: Sauria). Faunistische Abhandlungen, steatliches Museuem fur Tierkunde. Dresden, 21 (suppl.). In: Frittz, U., Obst, F.J. and Andreas, B., Eds., Herpetologia Arabica, 6, 34-66.

[9] Albert, R., Bibiane, B. and Watzka, M. (2004) Zur Vegetation und Flora Jordaniens. In: Waitzbauer, W., Albert, A., Petutrschnig, B. and Aubrecht, G., Eds., Reise Durch Die Natur Jordaniens. Denesia, 14, 133-220.

[10] Ruben, I. and Disi, A.M. (2006) Field guide to the plants and animals of Petra. Petra National Trust, 224 Pages.

[11] GCEP (General Corporation for Environmental Protection) (2000) Jordan country study on biological diversity, plant biodiversity and taxonomy. With technical support from UNEP and funding from GEF, Amman, Jordan, 72 Pages.

[12] Oran, S. (1995) Vascular plants of Shoubak Province. Dirasat, 23, 393-408.

[13] Oran, S. (1997) Plant diversity in Petra. Damascus University Journal, 13, 153-165.

[14] GCEP (General Corporation for Environmental Protection) (2000c) Jordan country study on biological diversity: Mammals of Jordan. With technical support from UNEP and funding from GEF, Amman, Jordan, 100 Pages.

[15] Disi, A.M. and Hatough-Bouran, A. (1999) Biodiversity of the terrestrial vertebrate fauna of Petra (Jordan). Caspopis Narodniho Muzea, Rada Prirodovedna. Journal of the National Museum Natural History, Series, Prague 168, 83-98.

[16] GCEP (General Corporation for Environmental Protection) (2000) Jordan country study on biological diversity: jordan ecology, ecosystems, and habitats. With technical support from UNEP and funding from GEF. Amman, Jordan, 72 Pages.

[17] Disi, A.M. (2002) Jordan country study on biological diversity-Herpetofauna of Jordan. With technical support from the United General Corporation for Environmental Protection.1998. Jordan Country Study on Biological Diversity. With Technical Support from UNEP and funding from GEF. Amman. Jordan. 416 Pages.

[18] RSCN (Royal Society for Conservation of Nature) (2000) Important bird areas of Jordan. RSCN, Birdlife International. Amman, Jordan, 170 Pages.

[19] Andrews, I.J. (1995) The birds of the Hashemite Kingdom of Jordan, 185 Pages.

[20] Disi, A.M., Hatough-Bopuran, A. and Shafei, D.M. (1998) Birds of Petra Area: Jordan. Dirasat. Natural and Engineering Sciences, 25, 434-444. 